Article

\title{
Fluoxetine Induced Suicidal Erythrocyte Death
}

\author{
Kashif Jilani ${ }^{1}$, Sigrid Enkel ${ }^{2}$, Rosi Bissinger ${ }^{1}$, Ahmad Almilaji ${ }^{1}$, Majed Abed ${ }^{1}$ and \\ Florian Lang ${ }^{1, *}$
}

1 Department of Physiology, University of Tuebingen, Gmelinstr. 5, Tuebingen 72076, Germany; E-Mails: kashif_cbc@yahoo.com (K.J.); ahmad_almilaji@yahoo.co.uk (A.A.); dr.magd81@hotmail.com (M.A.)

2 Zentrum für Klinische Transfusionsmedizin, Otfried-Müller-Straße 4/1, Tuebingen 72076, Germany; E-Mail: sigrid.enkel@med.uni-tuebingen.de

* Author to whom correspondence should be addressed; E-Mail: florian.lang@uni-tuebingen.de; Tel.: +49-7071-29-72194; Fax: +49-7071-29-5618.

Received: 23 May 2013; in revised form: 28 June 2013 / Accepted: 4 July 2013 /

Published: 15 July 2013

\begin{abstract}
The antidepressant fluoxetine inhibits ceramide producing acid sphingomyelinase. Ceramide is in turn known to trigger eryptosis the suicidal death of erythrocytes characterized by cell shrinkage and exposure of phosphatidylserine at the erythrocyte surface. Ceramide is effective through sensitizing the erythrocytes to the pro-eryptotic effect of increased cytosolic $\mathrm{Ca}^{2+}$ activity $\left(\left[\mathrm{Ca}^{2+}\right]_{\mathrm{i}}\right)$. In nucleated cells, fluoxetine could either inhibit or stimulate suicidal death or apoptosis. The present study tested whether fluoxetine influences eryptosis. To this end cell volume was estimated from forward scatter, phosphatidylserine exposure from annexin $\mathrm{V}$ binding, hemolysis from hemoglobin release and $\left[\mathrm{Ca}^{2+}\right]_{i}$ from Fluo-3 fluorescence intensity. As a result, a $48 \mathrm{~h}$ exposure of erythrocytes to fluoxetine $(\geq 25 \mu \mathrm{M})$ significantly decreased forward scatter, increased annexin $\mathrm{V}$ binding and enhanced $\left[\mathrm{Ca}^{2+}\right]_{\mathrm{i}}$. The effect on annexin $\mathrm{V}$ binding was significantly blunted, but not abolished, in the absence of extracellular $\mathrm{Ca}^{2+}$. In conclusion, fluoxetine stimulates eryptosis, an effect at least in part due to increase of cytosolic $\mathrm{Ca}^{2+}$ activity.
\end{abstract}

Keywords: phosphatidylserine; fluoxetine; calcium; cell volume; eryptosis 


\section{Introduction}

Fluoxetine is a widely used antidepressant [1,2], which has been shown to inhibit acid sphingomyelinase $[3,4]$. Sphingomyelinase activity generates ceramide, which in turn triggers suicidal death of nucleated cells [5] and erythrocytes [6]. In view of the inhibitory effect of fluoxetine on the sphingomyelinase, fluoxetine could be expected to inhibit suicidal death of erythrocytes or eryptosis [6]. As a matter of fact, fluoxetine has been shown to inhibit suicidal death or apoptosis of nucleated cells [7-9]. On the other hand, fluoxetine has been shown to trigger or foster apoptosis of nucleated cells $[10,11]$. The paper thus explored whether fluoxetine influences eryptosis.

Eryptosis is characterized by erythrocyte shrinkage and translocation of phosphatidylserine to the erythrocyte cell membrane surface [12]. Ceramide triggers eryptosis by sensitizing erythrocytes to the effects of increased cytosolic $\mathrm{Ca}^{2+}$ activity $\left(\left[\mathrm{Ca}^{2+}\right]_{\mathrm{i}}\right)[6]$. $\left[\mathrm{Ca}^{2+}\right]_{\mathrm{i}}$ may increase due to $\mathrm{Ca}^{2+}$ entry through $\mathrm{Ca}^{2+}$ permeable cation channels $[13,14]$. The increase of $\left[\mathrm{Ca}^{2+}\right]_{\mathrm{i}}$ is followed by cell shrinkage due to activation of $\mathrm{Ca}^{2+}$ sensitive $\mathrm{K}^{+}$channels [15], cellular $\mathrm{K}^{+}$exit, hyperpolarization of the cell membrane, $\mathrm{Cl}^{-}$exit and thus cellular loss of $\mathrm{KCl}$ with osmotically obliged water [16]. Increased $\left[\mathrm{Ca}^{2+}\right]_{\mathrm{i}}$ further triggers translocation of phosphatidylserine to the erythrocyte surface thus disrupting the phosphatidylserine asymmetry of the erythrocyte cell membrane [17]. Eryptosis is further elicited by energy depletion [18] and caspase activation [19-23]. Signaling governing eryptosis or erythrocyte survival includes several kinases, such as AMP activated kinase AMPK [14], cGMP dependent protein kinase [24], Janus activated kinase JAK3 [25], casein kinase [26,27], p38 kinase [28], PAK2 kinase [29] as well as sorafenib [30] and sunifinib [31] sensitive kinases.

The present study explored whether fluoxetine impacts on eryptosis. To this end, $\left[\mathrm{Ca}^{2+}\right]_{\mathrm{i}}$, cell volume and phosphatidylserine exposure at the cell surface were determined prior to and following fluoxetine exposure. As a result, fluoxetine increases $\left[\mathrm{Ca}^{2+}\right]_{\mathrm{i}}$, decreases erythrocyte volume and enhances the phosphatidylserine abundance at the erythrocyte surface.

\section{Methods}

\subsection{Erythrocytes, Solutions and Chemicals}

Leukocyte depleted erythrocytes were kindly provided by the blood bank of the University of Tübingen. The study is approved by the ethics committee of the University of Tübingen (184/2003V). Erythrocytes were incubated in vitro at a hematocrit of $0.4 \%$ in Ringer solution containing (in $\mathrm{mM}$ ) $125 \mathrm{NaCl}, 5 \mathrm{KCl}, 1 \mathrm{MgSO}_{4}$, 4-(2-hydroxyethyl)-1-piperazineethanesulfonic acid (HEPES), 5 glucose, $1 \mathrm{CaCl}_{2} ; \mathrm{pH} 7.4$ at $37{ }^{\circ} \mathrm{C}$ for $48 \mathrm{~h}$. Where indicated, erythrocytes were exposed to fluoxetine (Enzo, Lörrach, Germany) at the indicated concentrations. In $\mathrm{Ca}^{2+}$ free Ringer solution, $1 \mathrm{mM} \mathrm{CaCl} 2$ was substituted by $1 \mathrm{mM}$ glycol bis(2 aminoethylether)- $N, N, N^{\prime}, N^{\prime}$-tetraacetic acid (EGTA).

\subsection{FACS Analysis of Annexin V Binding and Forward Scatter}

After incubation under the respective experimental condition, $50 \mu \mathrm{L}$ cell suspension was washed in Ringer solution containing $5 \mathrm{mM} \mathrm{CaCl} 2$ and then stained with Annexin V FITC (1:200 dilution; ImmunoTools, Friesoythe, Germany) in this solution at $37{ }^{\circ} \mathrm{C}$ for $20 \mathrm{~min}$ under protection from light. Annexin $\mathrm{V}$ binding cells were defined according to the gating shown in the respective figure. In the 
following, the forward scatter (FSC) of the cells was determined, and annexin V fluorescence intensity was measured at an excitation wavelength of $488 \mathrm{~nm}$ and an emission wavelength of $530 \mathrm{~nm}$ on a FACS Calibur (BD, Heidelberg, Germany).

\subsection{Measurement of Intracellular $\mathrm{Ca}^{2+}$}

After incubation, erythrocytes were washed in Ringer solution and then loaded with Fluo 3/AM (Biotium, Hayward, USA) in Ringer solution containing $1 \mathrm{mM} \mathrm{CaCl}_{2}$ and $2 \mu \mathrm{M}$ Fluo 3/AM. The cells were incubated at $37{ }^{\circ} \mathrm{C}$ for $30 \mathrm{~min}$ and washed twice in Ringer solution containing $1 \mathrm{mM} \mathrm{CaCl}$. The Fluo 3/AM loaded erythrocytes were resuspended in $200 \mu \mathrm{L}$ Ringer. Then, $\mathrm{Ca}^{2+}$ dependent fluorescence intensity was measured at an excitation wavelength of $488 \mathrm{~nm}$ and an emission wavelength of $530 \mathrm{~nm}$ in FACS analysis.

\subsection{Measurement of Hemolysis}

For the determination of hemolysis, the samples were centrifuged ( $3 \mathrm{~min}$ at $400 \mathrm{~g}$, room temperature) after incubation, and the supernatants were harvested. As a measure of hemolysis, the hemoglobin $(\mathrm{Hb})$ concentration of the supernatant was determined photometrically at $405 \mathrm{~nm}$. The absorption of the supernatant of erythrocytes lysed in distilled water was defined as $100 \%$ hemolysis.

\subsection{Statistics}

Data are expressed as arithmetic means \pm SEM. Fluorescence intensities were shown in logarithmic scale. That means that neither of the populations shown in the histograms of Figures 1-4 are normally distributed. In Figures 1 and 2, cells with elevated fluorescence intensity (annexin-positive of PS-exposing cells) were gated as indicated by the marker. The percentage of PS-exposing cells was calculated for all blood samples. The percentages of PS-exposing cells of the individual blood samples was distributed normally (passed normality test), however, we have used now a non-parametric ANOVA (Kruskal-Wallis Test with Dunn post test using InStat software, Graphpad Software Inc., La Jolla, CA, USA) because there were significant differences among the standard deviations between groups (the scattering increased with increase in fluorescence intensities). $n$ denotes the number of different erythrocyte specimens studied. Since different erythrocyte specimens used in distinct experiments are differently susceptible to triggers of eryptosis, the same erythrocyte specimens have been used for control and experimental conditions.

\section{Results}

The present study analyzed the impact of fluoxetine on eryptosis, and the suicidal death of erythrocytes. A hallmark of eryptosis is cell shrinkage To possibly detect an effect of fluoxetine on cell volume, forward scatter was determined in FACS analysis as a measure of cell volume. As illustrated in Figure 1, a 48 h exposure of erythrocytes to fluoxetine was followed by a slight decrease of forward scatter, an effect reaching statistical significance at $25 \mu \mathrm{M}$ fluoxetine concentration. As a result, fluoxetine treatment was followed by erythrocyte shrinkage. 
Figure 1. Effect of fluoxetine on erythrocyte forward scatter. (A) Original histogram of forward scatter in erythrocytes following exposure for $48 \mathrm{~h}$ to Ringer solution without (grey shadow) and with (black line) presence of $50 \mu \mathrm{M}$ fluoxetine; (B) Arithmetic means \pm SEM $(n=12)$ of the normalized erythrocyte forward scatter (FSC) following incubation for $48 \mathrm{~h}$ to Ringer solution without (white bar) or with (black bars) fluoxetine $(1-50 \mu \mathrm{M}) . *(p<0.05)$ and $* * *(p<0.001)$ indicate significant difference from the absence of fluoxetine (ANOVA).

A

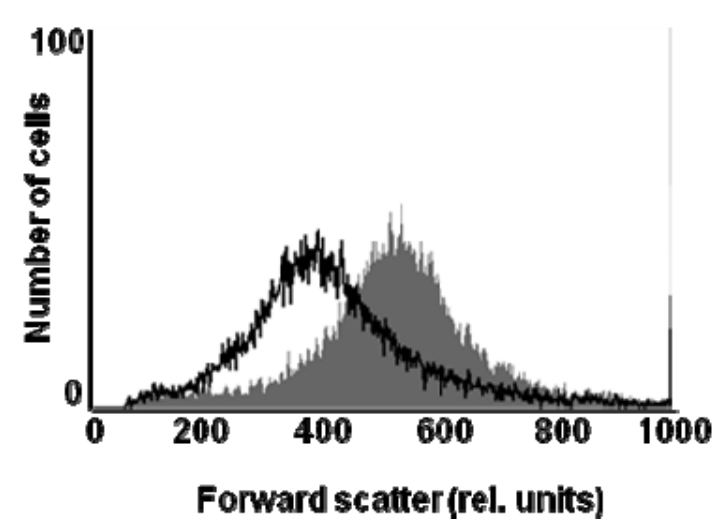

B

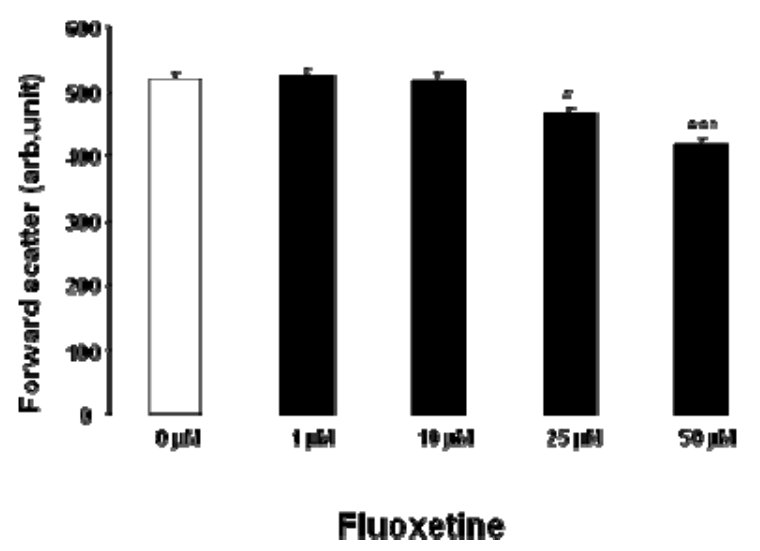

Figure 2. Effect of fluoxetine on phosphatidylserine exposure and hemolysis. (A) Original histogram of annexin $\mathrm{V}$ binding of erythrocytes following exposure for $48 \mathrm{~h}$ to Ringer solution without (grey shadow) and with (black line) presence of $50 \mu \mathrm{M}$ fluoxetine; (B) Arithmetic means $\pm \operatorname{SEM}(n=12)$ of erythrocyte annexin V binding following incubation for $48 \mathrm{~h}$ to Ringer solution without (white bar) or with (black bars) presence of fluoxetine $(1-50 \mu \mathrm{M})$. For comparison, arithmetic means $\pm \operatorname{SEM}(\mathrm{n}=4)$ of the percentage of hemolysis is shown as grey bars. $* *(p<0.01)$ and $* * *(p<0.001)$ indicate significant differences from the absence of fluoxetine (ANOVA).

A

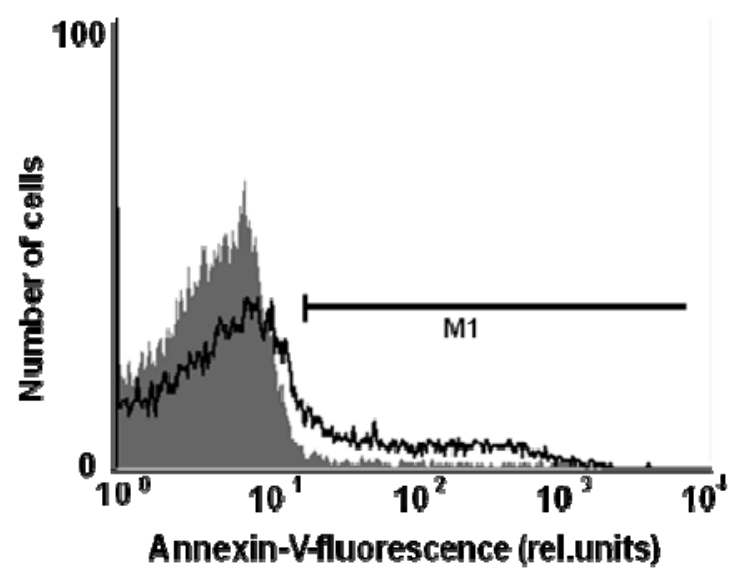

B

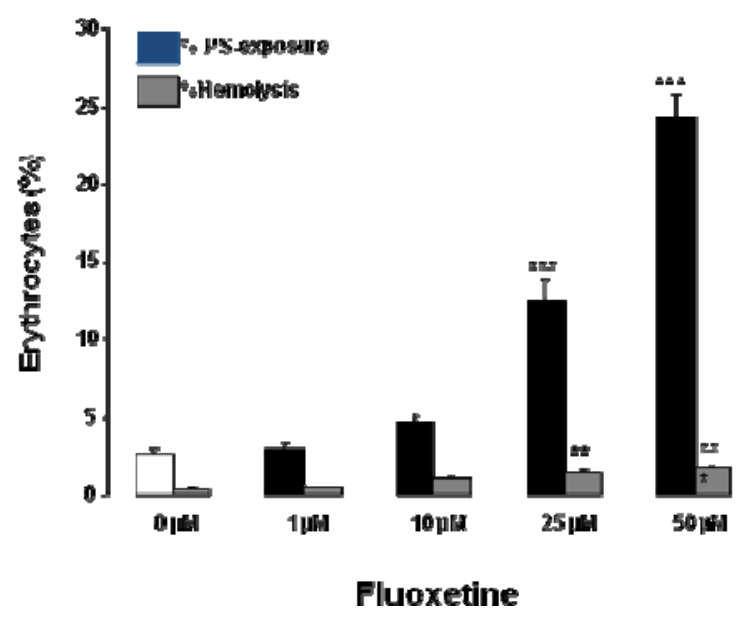


A further hallmark of eryptosis is cell membrane scrambling with breakdown of cell membrane phosphatidylserine asymmetry and exposure of phosphatidylserine at the cell surface. Phosphatidylserine abundance at the cell surface was thus estimated utilizing annexin V binding in FACS analysis. As illustrated in Figure 2, a $48 \mathrm{~h}$ treatment with fluoxetine $(1-50 \mu \mathrm{M})$ increased the percentage of annexin $\mathrm{V}$ binding erythrocytes, an effect reaching statistical significance at $25 \mu \mathrm{M}$ fluoxetine concentration. Thus, fluoxetine triggered cell membrane scrambling.

Further experiments explored whether fluoxetine triggered hemolysis, which was estimated by determination of hemoglobin in the supernatant. As shown in Figure 2, the percentage of hemolysed erythrocytes tended to increase slightly following exposure of erythrocytes for $48 \mathrm{~h}$ to fluoxetine, an effect reaching statistical significance at $25 \mu \mathrm{M}$ fluoxetine concentration (Figure 2). The percentage of hemolysed erythrocytes remained, however, one magnitude lower than the percentage of erythrocytes exposing phosphatidylserine.

Cell membrane scrambling could be triggered by increase of cytosolic $\mathrm{Ca}^{2+}$ activity $\left(\left[\mathrm{Ca}^{2+}\right]_{\mathrm{i}}\right)$. Thus, Fluo-3 fluorescence intensity was utilized to estimate $\left[\mathrm{Ca}^{2+}\right]_{\mathrm{i}}$. To this end, the erythrocytes were bathed for $48 \mathrm{~h}$ in Ringer solution without or with fluoxetine $(1-50 \mu \mathrm{M})$, loaded with Fluo-3-AM and Fluo-3 fluorescence intensity (arbitrary units) quantified by FACS analysis. As illustrated in Figure 3, a $48 \mathrm{~h}$ exposure of human erythrocytes to fluoxetine was followed by an increase of Fluo-3 fluorescence intensity, an effect reaching statistical significance at $50 \mu \mathrm{M}$ fluoxetine concentration. Thus, fluoxetine treatment was followed by increase of $\left[\mathrm{Ca}^{2+}\right]_{\mathrm{i}}$ in human erythrocytes.

Figure 3. Effect of fluoxetine on erythrocyte cytosolic $\mathrm{Ca}^{2+}$ concentration. (A) Original histogram of Fluo-3 fluorescence intensity (arbitrary units) in erythrocytes following exposure for $48 \mathrm{~h}$ to Ringer solution without (grey shadow) and with (black line) presence of $50 \mu \mathrm{M}$ fluoxetine; (B) Arithmetic means \pm SEM $(n=12)$ of the Fluo-3 mean fluorescence intensity (MFI) (arbitrary units) in erythrocytes exposed for $48 \mathrm{~h}$ to Ringer solution without (white bar) or with (black bars) fluoxetine $(1-50 \mu \mathrm{M})$. *** $(P<0.001)$ indicate significant difference from the absence of fluoxetine (ANOVA).

A

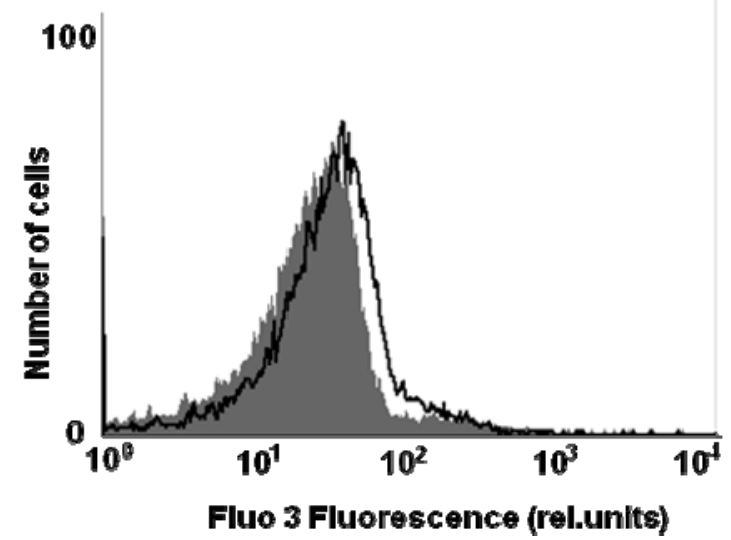

B

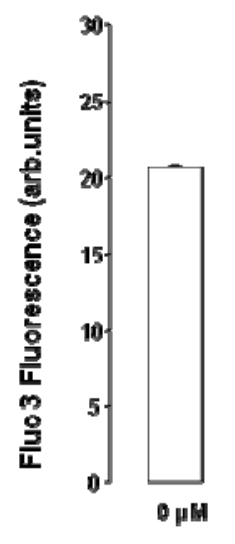

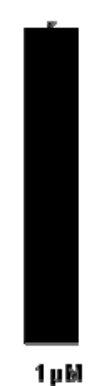

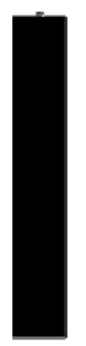

10 멉

Fluoxetine

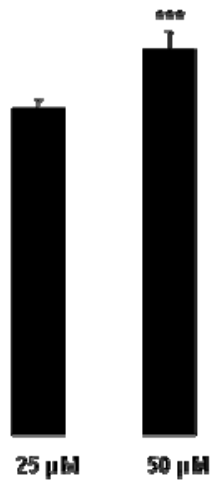

50 픈

In order to define the role of $\mathrm{Ca}^{2+}$ in the stimulation of cell membrane scrambling following fluoxetine treatment, experiments were performed either in the presence of $1 \mathrm{mM}$ extracellular $\mathrm{Ca}^{2+}$ or in the absence of extracellular $\mathrm{Ca}^{2+}$ and presence of the $\mathrm{Ca}^{2+}$ chelator EGTA (1 mM). As illustrated in 
Figure 4, exposure of erythrocytes to $50 \mu \mathrm{M}$ fluoxetine for $48 \mathrm{~h}$ significantly increased annexin $\mathrm{V}$ binding, an effect significantly less pronounced in the absence of extracellular $\mathrm{Ca}^{2+}$. Accordingly, $\mathrm{Ca}^{2+}$ removal significantly blunted the effect of fluoxetine $(50 \mu \mathrm{M})$ on annexin $\mathrm{V}$ binding. However, even in the absence of extracellular $\mathrm{Ca}^{2+}$ the percentage of annexin $\mathrm{V}$ binding erythrocytes was significantly increased by fluoxetine treatment (Figure 4). Thus, fluoxetine induced cell membrane scrambling was in part but not fully dependent on the presence of extracellular $\mathrm{Ca}^{2+}$.

Figure 4. Effect of $\mathrm{Ca}^{2+}$ withdrawal on fluoxetine induced annexin $\mathrm{V}$ binding. Arithmetic means $\pm \operatorname{SEM}(n=4)$ of the percentage of annexin $\mathrm{V}$ binding erythrocytes after a $48 \mathrm{~h}$ treatment with Ringer solution without (white bar) or with (black bars) $50 \mu \mathrm{M}$ fluoxetine in the presence (left bars, + Calcium) and absence (right bars, - Calcium) of calcium. $* * *(p<0.001)$ indicate significant difference from the absence of fluoxetine (ANOVA), \# $(p<0.05)$ indicates significant difference from the respective values in the presence of $\mathrm{Ca}^{2+}$.

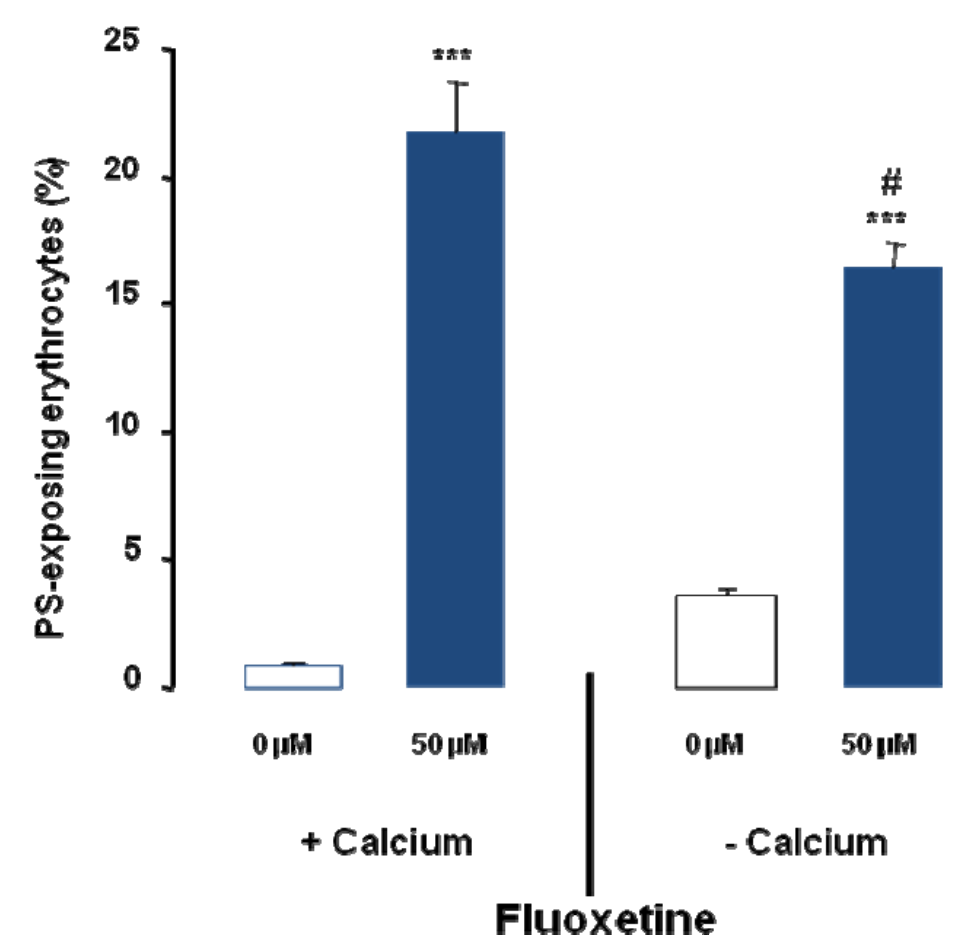

\section{Discussion}

The present study reveals a stimulatory effect of fluoxetine on eryptosis, the suicidal death of erythrocytes. The concentrations required to stimulate eryptosis are only moderately higher than the concentrations encountered in vivo [32,33]. In patients plasma concentrations of $2-3 \mu \mathrm{M}$ have been determined [34]. Thus, a stimulation of eryptosis is only expected at toxic dosages of fluoxetine or at a particular sensitivity of the erythrocytes. Sensitivity of individual patients to triggers of eryptosis could be enhanced by disease, intoxication and or treatment with other proeryptotic drugs. Along those lines, eryptosis is triggered by a wide variety of xenobiotics [31,35-67] and enhanced eryptosis contributes to the pathophysiology of several clinical disorders [12], such as diabetes $[23,68,69]$, renal insufficiency [70], hemolytic uremic syndrome [71], sepsis [72], malaria [73-77], sickle cell 
disease [78], Wilson's disease [76], iron deficiency [79], malignancy [80], phosphate depletion [81], and metabolic syndrome [61].

The fluoxetine induced cell membrane scrambling with breakdown of phosphatidylserine asymmetry of the erythrocyte cell membrane was significantly blunted in the absence of extracellular $\mathrm{Ca}^{2+}$ and was thus at least in part due to entry of extracellular $\mathrm{Ca}^{2+}$. An increase of cytosolic $\mathrm{Ca}^{2+}$ activity $\left(\left[\mathrm{Ca}^{2+}\right]_{\mathrm{i}}\right)$ is the main stimulator of cell membrane scrambling and subsequent phosphatidylserine translocation from the inner leaflet of the cell membrane to the outer leaflet of the cell membrane [12]. The $\mathrm{Ca}^{2+}$ entry is accomplished by $\mathrm{Ca}^{2+}$ permeable non selective cation channels involving the transient receptor potential channel TRPC6 [13]. The $\mathrm{Ca}^{2+}$ permeable cation channels in the erythrocyte cell membrane are activated by oxidative stress [82].

The erythrocyte shrinkage following fluoxetine treatment again presumably results from increase of $\left[\mathrm{Ca}^{2+}\right]_{\mathrm{i}}$, which activates $\mathrm{Ca}^{2+}$ sensitive $\mathrm{K}^{+}$channels $[15,83]$. The subsequent cell membrane hyperpolarization increases the electrical driving force for $\mathrm{Cl}^{-}$exit and the cellular loss of $\mathrm{KCl}$ with osmotically obliged water eventually leads to the observed cell shrinkage [16].

According to Fluo-3 fluorescence intensity, fluoxetine does increase cytosolic $\mathrm{Ca}^{2+}$ activity, an effect, however, reaching statistical significance only at high fluoxetine concentrations. The possibility must be considered that the sensitivity of Fluo-3 fluorescence for the measurement of cytosolic $\mathrm{Ca}^{2+}$ activity may be limited and thus higher concentrations of cytosolic $\mathrm{Ca}^{2+}$ activity are required to significantly detect alterations of Fluo-3 fluorescence intensity than the cytosolic $\mathrm{Ca}^{2+}$ concentrations required to trigger cell membrane scrambling resulting in statistically significant increases of annexin $\mathrm{V}$ binding. Nevertheless, even in the nominal absence of extracellular $\mathrm{Ca}^{2+}$ fluoxetine still significantly increases annexin $\mathrm{V}$ binding, i.e., cell membrane scrambling. Thus, additional mechanisms are presumably involved in the stimulation of erythrocyte membrane scrambling by fluoxetine. Eryptosis could be triggered by oxidative stress or weakened antioxidant defence [47,82,84]. Moreover, eryptosis could be triggered by energy depletion [18]. Eryptosis could further be stimulated or fostered by caspase activation [19-23], by stimulation of Janus activated kinase JAK3 [25], casein kinase [26,27], p38 kinase [28] and PAK2 kinases [29] or by inhibition of AMP activated kinase AMPK [14] and cGMP dependent protein kinase [24].

A stimulation of eryptosis may result in anemia. Eryptotic erythrocytes are rapidly removed from circulating blood [12]. As long as the accelerated loss of erythrocytes by stimulated eryptosis is matched by a similar stimulation of erythropoiesis, the blood count may remain almost constant. As soon as the enhanced erythropoiesis cannot compensate for the excessive eryptosis, anemia develops [12].

Excessive eryptosis may further lead to adhesion of phosphatidylserine exposing erythrocytes to endothelial CXCL16/SR PSO [85]. At least in theory, erythrocyte adhesion to the vascular wall could compromize microcirculation and thus interfere with blood flow [85-90]. The interference of eryptosis with microcirculation may be compounded by the stimulating effect of phosphatidylserine exposure on blood clotting with subsequent triggering of thrombosis $[86,91,92]$. 


\section{Conclusions}

Toxic concentrations of the antidepressant fluoxetine stimulates eryptosis, the suicidal erythrocyte death.

\section{Acknowledgements}

The authors acknowledge the meticulous preparation of the manuscript by Ali Soleimanpour. The study was supported by the Deutsche Forschungsgemeinschaft.

\section{Conflict of Interests}

The authors declare no conflict of interest.

\section{References}

1. Martinotti, G.; Sepede, G.; Signorelli, M.; Aguglia, E.; Di Giannantonio, M. Efficacy and safety of fluoxetine monotherapy in bipolar depression: A systematic review. Expert Opin. Pharmacother. 2013, 14, 1065-1075.

2. Dubovsky, S.L. Pharmacokinetic evaluation of olanzapine + fluoxetine for the treatment of bipolar depression. Expert Opin. Drug Metab. Toxicol. 2013, 9, 207-214.

3. Becker, K.A.; Riethmuller, J.; Luth, A.; Doring, G.; Kleuser, B.; Gulbins, E. Acid sphingomyelinase inhibitors normalize pulmonary ceramide and inflammation in cystic fibrosis. Am. J. Respir. Cell Mol. Biol. 2010, 42, 716-724.

4. Kornhuber, J.; Tripal, P.; Gulbins, E.; Muehlbacher, M. Functional inhibitors of acid sphingomyelinase (fiasmas). Handb. Exp. Pharmacol. 2013, 215, 169-186.

5. Mullen, T.D.; Obeid, L.M. Ceramide and apoptosis: Exploring the enigmatic connections between sphingolipid metabolism and programmed cell death. Anticancer Agents Med. Chem. 2012, 12 , 340-363.

6. Lang, F.; Gulbins, E.; Lang, P.A.; Zappulla, D.; Foller, M. Ceramide in suicidal death of erythrocytes. Cell. Physiol. Biochem. 2010, 26, 21-28.

7. Wang, Y.; Zhang, X.H.; Wang, H.L. Involvement of bmpr2 in the protective effect of fluoxetine against monocrotaline-induced endothelial apoptosis in rats. Can. J. Physiol. Pharmacol. 2011, 89, 345-354.

8. Choi, M.R.; Oh, D.H.; Kim, S.H.; Yang, B.H.; Lee, J.S.; Choi, J.; Jeon, H.S.; Chai, Y.G.; Park, Y.C. Fluoxetine up-regulates bcl-xl expression in rat c6 glioma cells. Psychiatry Investig. 2011, 8, 161-168.

9. Ohira, K.; Takeuchi, R.; Shoji, H.; Miyakawa, T. Fluoxetine-induced cortical adult neurogenesis. Neuropsychopharmacol. Off. Public. Am. College Neuropsychopharmacol. 2013, 38, 909-920.

10. Djordjevic, J.; Djordjevic, A.; Adzic, M.; Elakovic, I.; Matic, G.; Radojcic, M.B. Fluoxetine affects antioxidant system and promotes apoptotic signaling in wistar rat liver. Eur. J. Pharmacol. 2011, Epub ahead of print, doi:10.1016/j.ejphar.2011.03.003. 
11. Kannen, V.; Hintzsche, H.; Zanette, D.L.; Silva, W.A., Jr.; Garcia, S.B.; Waaga-Gasser, A.M.; Stopper, H. Antiproliferative effects of fluoxetine on colon cancer cells and in a colonic carcinogen mouse model. PloS One 2012, 7, e50043.

12. Lang, F.; Gulbins, E.; Lerche, H.; Huber, S.M.; Kempe, D.S.; Foller, M. Eryptosis, a window to systemic disease. Cell. Physiol. Biochem. 2008, 22 373-380.

13. Foller, M.; Kasinathan, R.S.; Koka, S.; Lang, C.; Shumilina, E.; Birnbaumer, L.; Lang, F.; Huber, S.M. Trpc6 contributes to the ca(2+) leak of human erythrocytes. Cell. Physiol. Biochem. 2008, 21, 183-192.

14. Foller, M.; Sopjani, M.; Koka, S.; Gu, S.; Mahmud, H.; Wang, K.; Floride, E.; Schleicher, E.; Schulz, E.; Munzel, T.; et al. Regulation of erythrocyte survival by amp-activated protein kinase. FASEB J. 2009, 23, 1072-1080.

15. Brugnara, C.; de Franceschi, L.; Alper, S.L. Inhibition of ca(2+)-dependent $\mathrm{k}+$ transport and cell dehydration in sickle erythrocytes by clotrimazole and other imidazole derivatives. J. Clin. Invest. 1993, 92, 520-526.

16. Lang, P.A.; Kaiser, S.; Myssina, S.; Wieder, T.; Lang, F.; Huber, S.M. Role of ca2+-activated k+ channels in human erythrocyte apoptosis. Am. J. Physiol. Cell Physiol. 2003, 285, C1553-C1560.

17. Berg, C.P.; Engels, I.H.; Rothbart, A.; Lauber, K.; Renz, A.; Schlosser, S.F.; Schulze-Osthoff, K.; Wesselborg, S. Human mature red blood cells express caspase-3 and caspase-8, but are devoid of mitochondrial regulators of apoptosis. Cell Death. Differ. 2001, 8, 1197-1206.

18. Klarl, B.A.; Lang, P.A.; Kempe, D.S.; Niemoeller, O.M.; Akel, A.; Sobiesiak, M.; Eisele, K.; Podolski, M.; Huber, S.M.; Wieder, T.; et al. Protein kinase c mediates erythrocyte "programmed cell death" following glucose depletion. Am. J. Physiol. Cell Physiol. 2006, 290, C244-C253.

19. Bhavsar, S.K.; Bobbala, D.; Xuan, N.T.; Foller, M.; Lang, F. Stimulation of suicidal erythrocyte death by alpha-lipoic acid. Cell. Physiol. Biochem. 2010, 26, 859-868.

20. Foller, M.; Huber, S.M.; Lang, F. Erythrocyte programmed cell death. IUBMB Life 2008, 60, 661-668.

21. Foller, M.; Mahmud, H.; Gu, S.; Wang, K.; Floride, E.; Kucherenko, Y.; Luik, S.; Laufer, S.; Lang, F. Participation of leukotriene c(4) in the regulation of suicidal erythrocyte death. J. Physiol. Pharmacol. 2009, 60, 135-143.

22. Lau, I.P.; Chen, H.; Wang, J.; Ong, H.C.; Leung, K.C.; Ho, H.P.; Kong, S.K. In vitro effect of ctab- and peg-coated gold nanorods on the induction of eryptosis/erythroptosis in human erythrocytes. Nanotoxicology.2012, 6, 847-856.

23. Maellaro, E.; Leoncini, S.; Moretti, D.; Del Bello, B.; Tanganelli, I.; De Felice, C.; Ciccoli, L. Erythrocyte caspase-3 activation and oxidative imbalance in erythrocytes and in plasma of type 2 diabetic patients. Acta Diabetol. 2011, Epub ahead of print, doi:10.1007/s00592-011-0274-0.

24. Foller, M.; Feil, S.; Ghoreschi, K.; Koka, S.; Gerling, A.; Thunemann, M.; Hofmann, F.; Schuler, B.; Vogel, J.; Pichler, B.; et al. Anemia and splenomegaly in cgki-deficient mice. Proc. Natl. Acad. Sci. USA 2008, 105, 6771-6776.

25. Bhavsar, S.K.; Gu, S.; Bobbala, D.; Lang, F. Janus kinase 3 is expressed in erythrocytes, phosphorylated upon energy depletion and involved in the regulation of suicidal erythrocyte death. Cell. Physiol. Biochem. 2011, 27, 547-556. 
26. Kucherenko, Y.; Zelenak, C.; Eberhard, M.; Qadri, S.M.; Lang, F. Effect of casein kinase 1alpha activator pyrvinium pamoate on erythrocyte ion channels. Cell. Physiol. Biochem. 2012, 30, 407-417.

27. Zelenak, C.; Eberhard, M.; Jilani, K.; Qadri, S.M.; Macek, B.; Lang, F. Protein kinase ck1alpha regulates erythrocyte survival. Cell. Physiol. Biochem. 2012, 29, 171-180.

28. Gatidis, S.; Zelenak, C.; Fajol, A.; Lang, E.; Jilani, K.; Michael, D.; Qadri, S.M.; Lang, F. P38 mapk activation and function following osmotic shock of erythrocytes. Cell. Physiol. Biochem. 2011, 28, 1279-1286.

29. Zelenak, C.; Foller, M.; Velic, A.; Krug, K.; Qadri, S.M.; Viollet, B.; Lang, F.; Macek, B. Proteome analysis of erythrocytes lacking amp-activated protein kinase reveals a role of pak2 kinase in eryptosis. J. Proteome Res. 2011, 10, 1690-1697.

30. Lupescu, A.; Shaik, N.; Jilani, K.; Zelenak, C.; Lang, E.; Pasham, V.; Zbidah, M.; Plate, A.; Bitzer, M.; Foller, M.; et al. Enhanced erythrocyte membrane exposure of phosphatidylserine following sorafenib treatment: An in vivo and in vitro study. Cell. Physiol. Biochem. 2012, 30, 876-888.

31. Shaik, N.; Lupescu, A.; Lang, F. Sunitinib-sensitive suicidal erythrocyte death. Cell. Physiol. Biochem. 2012, 30, 512-522.

32. Dulawa, S.C.; Holick, K.A.; Gundersen, B.; Hen, R. Effects of chronic fluoxetine in animal models of anxiety and depression. Neuropsychopharmacol. Off. Public. Am. College Neuropsychopharmacol. 2004, 29, 1321-1330.

33. Holladay, J.W.; Dewey, M.J.; Yoo, S.D. Pharmacokinetics and antidepressant activity of fluoxetine in transgenic mice with elevated serum alpha-1-acid glycoprotein levels. Drug Metab. Dispos. 1998, 26, 20-24.

34. Pato, M.T.; Murphy, D.L.; DeVane, C.L. Sustained plasma concentrations of fluoxetine and/or norfluoxetine four and eight weeks after fluoxetine discontinuation. J. Clin. Psychopharmacol. 1991, 11, 224-225.

35. Abed, M.; Towhid, S.T.; Mia, S.; Pakladok, T.; Alesutan, I.; Borst, O.; Gawaz, M.; Gulbins, E.; Lang, F. Sphingomyelinase-induced adhesion of eryptotic erythrocytes to endothelial cells. Am. J. Physiol. Cell Physiol. 2012, 303, C991-C999.

36. Abed, M.; Towhid, S.T.; Shaik, N.; Lang, F. Stimulation of suicidal death of erythrocytes by rifampicin. Toxicology 2012, 302, 123-128.

37. Bottger, E.; Multhoff, G.; Kun, J.F.; Esen, M. Plasmodium falciparum-infected erythrocytes induce granzyme b by nk cells through expression of host-hsp70. PloS One 2012, 7, e33774.

38. Felder, K.M.; Hoelzle, K.; Ritzmann, M.; Kilchling, T.; Schiele, D.; Heinritzi, K.; Groebel, K.; Hoelzle, L.E. Hemotrophic mycoplasmas induce programmed cell death in red blood cells. Cell. Physiol. Biochem. 2011, 27, 557-564.

39. Firat, U.; Kaya, S.; Cim, A.; Buyukbayram, H.; Gokalp, O.; Dal, M.S.; Tamer, M.N. Increased caspase-3 immunoreactivity of erythrocytes in stz diabetic rats. Exp. Diabetes Res. 2012, 2012, 316384. 
40. Ganesan, S.; Chaurasiya, N.D.; Sahu, R.; Walker, L.A.; Tekwani, B.L. Understanding the mechanisms for metabolism-linked hemolytic toxicity of primaquine against glucose 6-phosphate dehydrogenase deficient human erythrocytes: Evaluation of eryptotic pathway. Toxicology 2012, 294, 54-60.

41. Gao, M.; Cheung, K.L.; Lau, I.P.; Yu, W.S.; Fung, K.P.; Yu, B.; Loo, J.F.; Kong, S.K. Polyphyllin $\mathrm{d}$ induces apoptosis in human erythrocytes through $\mathrm{ca}(2)(+)$ rise and membrane permeabilization. Arch. Toxicol. 2012, 86, 741-752.

42. Ghashghaeinia, M.; Cluitmans, J.C.; Akel, A.; Dreischer, P.; Toulany, M.; Koberle, M.; Skabytska, Y.; Saki, M.; Biedermann, T.; Duszenko, M.; et al. The impact of erythrocyte age on eryptosis. Br. J. Haematol. 2012, 157, 606-614.

43. Ghashghaeinia, M.; Toulany, M.; Saki, M.; Bobbala, D.; Fehrenbacher, B.; Rupec, R.; Rodemann, H.P.; Ghoreschi, K.; Rocken, M.; Schaller, M.; et al. The nfkb pathway inhibitors bay 11-7082 and parthenolide induce programmed cell death in anucleated erythrocytes. Cell. Physiol. Biochem. 2011, 27, 45-54.

44. Jilani, K.; Lupescu, A.; Zbidah, M.; Abed, M.; Shaik, N.; Lang, F. Enhanced apoptotic death of erythrocytes induced by the mycotoxin ochratoxin a. Kidney Blood Press Res. 2012, 36, 107-118.

45. Jilani, K.; Lupescu, A.; Zbidah, M.; Shaik, N.; Lang, F. Withaferin a-stimulated ca(2+) entry, ceramide formation and suicidal death of erythrocytes. Toxicol. in Vitro. 2013, 27, 52-58..

46. Kucherenko, Y.V.; Lang, F. Inhibitory effect of furosemide on non-selective voltage-independent cation channels in human erythrocytes. Cell. Physiol. Biochem. 2012, 30, 863-875.

47. Lang, E.; Jilani, K.; Zelenak, C.; Pasham, V.; Bobbala, D.; Qadri, S.M.; Lang, F. Stimulation of suicidal erythrocyte death by benzethonium. Cell. Physiol. Biochem. 2011, 28, 347-354.

48. Lang, E.; Qadri, S.M.; Jilani, K.; Zelenak, C.; Lupescu, A.; Schleicher, E.; Lang, F. Carbon monoxide-sensitive apoptotic death of erythrocytes. Basic Clin. Pharmacol. Toxicol. 2012, 111, 348-355.

49. Lang, F.; Qadri, S.M. Mechanisms and significance of eryptosis, the suicidal death of erythrocytes. Blood Purif. 2012, 33, 125-130.

50. Lupescu, A.; Jilani, K.; Zbidah, M.; Lang, E.; Lang, F. Enhanced ca(2+) entry, ceramide formation, and apoptotic death of erythrocytes triggered by plumbagin. J. Nat. Prod. 2012, 75, 1956-1961.

51. Lupescu, A.; Jilani, K.; Zbidah, M.; Lang, F. Induction of apoptotic erythrocyte death by rotenone. Toxicology 2012, 300, 132-137.

52. Lupescu, A.; Jilani, K.; Zelenak, C.; Zbidah, M.; Qadri, S.M.; Lang, F. Hexavalent chromium-induced erythrocyte membrane phospholipid asymmetry. Biometals 2012, 25, 309-318.

53. Polak-Jonkisz, D.; Purzyc, L. Ca influx versus efflux during eryptosis in uremic erythrocytes. Blood Purif. 2012, 34, 209-210.

54. Qadri, S.M.; Bauer, J.; Zelenak, C.; Mahmud, H.; Kucherenko, Y.; Lee, S.H.; Ferlinz, K.; Lang, F. Sphingosine but not sphingosine-1-phosphate stimulates suicidal erythrocyte death. Cell. Physiol. Biochem. 2011, 28, 339-346.

55. Qadri, S.M.; Kucherenko, Y.; Lang, F. Beauvericin induced erythrocyte cell membrane scrambling. Toxicology 2011, 283, 24-31. 
56. Qadri, S.M.; Kucherenko, Y.; Zelenak, C.; Jilani, K.; Lang, E.; Lang, F. Dicoumarol activates ca2+-permeable cation channels triggering erythrocyte cell membrane scrambling. Cell. Physiol. Biochem. 2011, 28, 857-864.

57. Qian, E.W.; Ge, D.T.; Kong, S.K. Salidroside protects human erythrocytes against hydrogen peroxide-induced apoptosis. J. Nat. Prod. 2012, 75, 531-537.

58. Shaik, N.; Zbidah, M.; Lang, F. Inhibition of ca(2+) entry and suicidal erythrocyte death by naringin. Cell. Physiol. Biochem. 2012, 30, 678-686.

59. Vota, D.M.; Maltaneri, R.E.; Wenker, S.D.; Nesse, A.B.; Vittori, D.C. Differential erythropoietin action upon cells induced to eryptosis by different agents. Cell Biochem. Biophys. 2013, 65, 145-157.

60. Weiss, E.; Cytlak, U.M.; Rees, D.C.; Osei, A.; Gibson, J.S. Deoxygenation-induced and ca(2+) dependent phosphatidylserine externalisation in red blood cells from normal individuals and sickle cell patients. Cell Calcium 2012, 51, 51-56.

61. Zappulla, D. Environmental stress, erythrocyte dysfunctions, inflammation, and the metabolic syndrome: Adaptations to co2 increases? J. Cardiometab. Syndr. 2008, 3, 30-34.

62. Zbidah, M.; Lupescu, A.; Jilani, K.; Lang, F. Stimulation of suicidal erythrocyte death by fumagillin. Basic Clin. Pharmacol. Toxicol. 2013, 112, 346-351.

63. Zbidah, M.; Lupescu, A.; Shaik, N.; Lang, F. Gossypol-induced suicidal erythrocyte death. Toxicology 2012, 302, 101-105.

64. Zelenak, C.; Pasham, V.; Jilani, K.; Tripodi, P.M.; Rosaclerio, L.; Pathare, G.; Lupescu, A.; Faggio, C.; Qadri, S.M.; Lang, F. Tanshinone iia stimulates erythrocyte phosphatidylserine exposure. Cell. Physiol. Biochem. 2012, 30, 282-294.

65. Lang, E.; Qadri, S.M.; Lang, F. Killing me softly - suicidal erythrocyte death. Int. J. Biochem. Cell Biol. 2012, 44, 1236-1243.

66. Ghashghaeinia, M.; Bobbala, D.; Wieder, T.; Koka, S.; Bruck, J.; Fehrenbacher, B.; Rocken, M.; Schaller, M.; Lang, F.; Ghoreschi, K. Targeting glutathione by dimethylfumarate protects against experimental malaria by enhancing erythrocyte cell membrane scrambling. Am. J. Physiol. Cell Physiol. 2010, 299, C791-C804.

67. Ahmed, M.S.; Langer, H.; Abed, M.; Voelk1, J.; Lang, F. The uremic toxin acrolein promotes suicidal erythrocyte death. Kideny Blood Pressure Res. 2013, 37, 158-167.

68. Calderon-Salinas, J.V.; Munoz-Reyes, E.G.; Guerrero-Romero, J.F.; Rodriguez-Moran, M.; Bracho-Riquelme, R.L.; Carrera-Gracia, M.A.; Quintanar-Escorza, M.A. Eryptosis and oxidative damage in type 2 diabetic mellitus patients with chronic kidney disease. Mol. Cell Biochem. 2011, $357,171-179$.

69. Nicolay, J.P.; Schneider, J.; Niemoeller, O.M.; Artunc, F.; Portero-Otin, M.; Haik, G., Jr.; Thornalley, P.J.; Schleicher, E.; Wieder, T.; Lang, F. Stimulation of suicidal erythrocyte death by methylglyoxal. Cell. Physiol. Biochem. 2006, 18, 223-232.

70. Myssina, S.; Huber, S.M.; Birka, C.; Lang, P.A.; Lang, K.S.; Friedrich, B.; Risler, T.; Wieder, T.; Lang, F. Inhibition of erythrocyte cation channels by erythropoietin. J. Am. Soc. Nephrol. 2003, 14, 2750-2757. 
71. Lang, P.A.; Beringer, O.; Nicolay, J.P.; Amon, O.; Kempe, D.S.; Hermle, T.; Attanasio, P.; Akel, A.; Schafer, R.; Friedrich, B.; et al. Suicidal death of erythrocytes in recurrent hemolytic uremic syndrome. J. Mol. Med. 2006, 84, 378-388.

72. Kempe, D.S.; Akel, A.; Lang, P.A.; Hermle, T.; Biswas, R.; Muresanu, J.; Friedrich, B.; Dreischer, P.; Wolz, C.; Schumacher, U.; et al. Suicidal erythrocyte death in sepsis. J. Mol. Med. 2007, 85, 269-277.

73. Bobbala, D.; Alesutan, I.; Foller, M.; Huber, S.M.; Lang, F. Effect of anandamide in plasmodium berghei-infected mice. Cell. Physiol Biochem. 2010, 26, 355-362.

74. Foller, M.; Bobbala, D.; Koka, S.; Huber, S.M.; Gulbins, E.; Lang, F. Suicide for survival--death of infected erythrocytes as a host mechanism to survive malaria. Cell. Physiol. Biochem. 2009, 24, 133-140.

75. Koka, S.; Bobbala, D.; Lang, C.; Boini, K.M.; Huber, S.M.; Lang, F. Influence of paclitaxel on parasitemia and survival of plasmodium berghei infected mice. Cell. Physiol. Biochem. 2009, 23, 191-198.

76. Lang, P.A.; Schenck, M.; Nicolay, J.P.; Becker, J.U.; Kempe, D.S.; Lupescu, A.; Koka, S.; Eisele, K.; Klarl, B.A.; Rubben, H.; et al. Liver cell death and anemia in wilson disease involve acid sphingomyelinase and ceramide. Nat. Med. 2007, 13, 164-170.

77. Siraskar, B.; Ballal, A.; Bobbala, D.; Foller, M.; Lang, F. Effect of amphotericin b on parasitemia and survival of plasmodium berghei-infected mice. Cell. Physiol. Biochem. 2010, 26, 347-354.

78. Lang, P.A.; Kasinathan, R.S.; Brand, V.B.; Duranton, C.; Lang, C.; Koka, S.; Shumilina, E.; Kempe, D.S.; Tanneur, V.; Akel, A.; et al. Accelerated clearance of plasmodium-infected erythrocytes in sickle cell trait and annexin-a7 deficiency. Cell. Physiol. Biochem. 2009, 24, 415-428.

79. Kempe, D.S.; Lang, P.A.; Duranton, C.; Akel, A.; Lang, K.S.; Huber, S.M.; Wieder, T.; Lang, F. Enhanced programmed cell death of iron-deficient erythrocytes. FASEB J. 2006, 20, 368-370.

80. Qadri, S.M.; Mahmud, H.; Lang, E.; Gu, S.; Bobbala, D.; Zelenak, C.; Jilani, K.; Siegfried, A.; Foller, M.; Lang, F. Enhanced suicidal erythrocyte death in mice carrying a loss-of-function mutation of the adenomatous polyposis coli gene. J. Cell Mol. Med. 2012, 16, 1085-1093.

81. Birka, C.; Lang, P.A.; Kempe, D.S.; Hoefling, L.; Tanneur, V.; Duranton, C.; Nammi, S.; Henke, G.; Myssina, S.; Krikov, M.; et al. Enhanced susceptibility to erythrocyte "apoptosis" following phosphate depletion. Pflugers Arch. 2004, 448, 471-477.

82. Brand, V.B.; Sandu, C.D.; Duranton, C.; Tanneur, V.; Lang, K.S.; Huber, S.M.; Lang, F. Dependence of plasmodium falciparum in vitro growth on the cation permeability of the human host erythrocyte. Cell. Physiol. Biochem. 2003, 13, 347-356.

83. Bookchin, R.M.; Ortiz, O.E.; Lew, V.L. Activation of calcium-dependent potassium channels in deoxygenated sickled red cells. Prog. Clin. Biol. Res. 1987, 240, 193-200.

84. Foller, M.; Harris, I.S.; Elia, A.; John, R.; Lang, F.; Kavanagh, T.J.; Mak, T.W. Functional significance of glutamate-cysteine ligase modifier for erythrocyte survival in vitro and in vivo. Cell. Death Different. 2013, Epub ahead of print, doi:10.1038/cdd.2013.70.

85. Borst, O.; Abed, M.; Alesutan, I.; Towhid, S.T.; Qadri, S.M.; Foller, M.; Gawaz, M.; Lang, F. Dynamic adhesion of eryptotic erythrocytes to endothelial cells via cxcl16/sr-psox. Am. J. Physiol. Cell Physiol. 2012, 302, C644-C651. 
86. Andrews, D.A.; Low, P.S. Role of red blood cells in thrombosis. Curr. Opin. Hematol. 1999, 6, 76-82.

87. Closse, C.; Dachary-Prigent, J.; Boisseau, M.R. Phosphatidylserine-related adhesion of human erythrocytes to vascular endothelium. Br. J. Haematol. 1999, 107, 300-302.

88. Gallagher, P.G.; Chang, S.H.; Rettig, M.P.; Neely, J.E.; Hillery, C.A.; Smith, B.D.; Low, P.S. Altered erythrocyte endothelial adherence and membrane phospholipid asymmetry in hereditary hydrocytosis. Blood 2003, 101, 4625-4627.

89. Pandolfi, A.; Di Pietro, N.; Sirolli, V.; Giardinelli, A.; Di Silvestre, S.; Amoroso, L.; Di Tomo, P.; Capani, F.; Consoli, A.; Bonomini, M. Mechanisms of uremic erythrocyte-induced adhesion of human monocytes to cultured endothelial cells. J. Cell Physiol. 2007, 213, 699-709.

90. Wood, B.L.; Gibson, D.F.; Tait, J.F. Increased erythrocyte phosphatidylserine exposure in sickle cell disease: Flow-cytometric measurement and clinical associations. Blood 1996, 88, 1873-1880.

91. Chung, S.M.; Bae, O.N.; Lim, K.M.; Noh, J.Y.; Lee, M.Y.; Jung, Y.S.; Chung, J.H. Lysophosphatidic acid induces thrombogenic activity through phosphatidylserine exposure and procoagulant microvesicle generation in human erythrocytes. Arterioscler. Thromb. Vasc. Biol. 2007, 27, 414-421.

92. Zwaal, R.F.; Comfurius, P.; Bevers, E.M. Surface exposure of phosphatidylserine in pathological cells. Cell Mol. Life Sci. 2005, 62, 971-988.

(C) 2013 by the authors; licensee MDPI, Basel, Switzerland. This article is an open access article distributed under the terms and conditions of the Creative Commons Attribution license (http://creativecommons.org/licenses/by/3.0/). 